


\section{Glasilo Future}

\section{Stručno-znanstveni časopis}

Nakladnik:

FUTURA

\section{FuTUR}

Sjedište udruge: Šibenik
Adresa uredništva:

Bana Josipa Jelačića 13 a, 22000 Šibenik, Hrvatska / Croatia

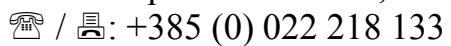

凶: urednistvo@gazette-future.eu / editors@gazette-future.eu

(3): www.gazette-future.eu

Uređivački odbor / Editorial Board:

Doc. dr. sc. Boris Dorbić, v. pred. - glavni i odgovorni urednik / Editor-in-Chief

Emilija Friganović, dipl. ing. preh. teh., v. pred. - zamjenica g. i o. urednika / Deputy Editor-in-Chief

Ančica Sečan Matijaščić, mag. act. soc. - tehnička urednica / Technical Editor

Antonia Dorbić, mag. art. - zamjenica tehničke urednice / Deputy Technical Editor

Prof. dr. sc. Željko Španjol

Mr. sc. Milivoj Blažević

Vesna Štibrić, dipl. ing. preh. teh.

Međunarodno uredništvo / International Editorial Board:

Prof. dr. sc. Kiril Bahcevandziev - Portugal (Instituto Politécnico de Coimbra)

Prof. dr. sc. Martin Bobinac - Srbija (Šumarski fakultet Beograd)

Prof. dr. sc. Zvezda Bogevska - Sjeverna Makedonija (Fakultet za zemjodelski nauki i hrana Skopje)

Dario Bognolo, mag. ing. - Hrvatska (Veleučilište u Rijeci)

Prof. dr. sc. Agata Cieszewska - Poljska (Szkoła Główna Gospodarstwa Wiejskiego w Warszawie)

Dr. sc. Bogdan Cvjetković, prof. emeritus - Hrvatska (Agronomski fakultet Zagreb)

Prof. dr. sc. Duška Ćurić - Hrvatska (Prehrambeno-biotehnološki fakultet Zagreb)

Prof. dr. sc. Margarita Davitkovska - Sjeverna Makedonija (Fakultet za zemjodelski nauki i hrana Skopje)

Prof. dr. sc. Dubravka Dujmović Purgar - Hrvatska (Agronomski fakultet Zagreb)

Prof. dr. sc. Josipa Giljanović - Republika Hrvatska (Kemijsko-tehnološki fakultet u Splitu)

Prof. dr. sc. Semina Hadžiabulić - Bosna i Hercegovina (Agromediteranski fakultet Mostar)

Prof. dr. sc. Péter Honfi - Mađarska (Faculty of Horticultural Science Budapest)

Prof. dr. sc. Valeria Ivanova - Bugarska (Fakultet za lozaro - gradinarstvo Plovdiv)

Prof. dr. sc. Mladen Ivić - Bosna i Hercegovina (Univerzitet PIM)

Doc. dr. sc. Orhan Jašić - Bosna i Hercegovina (Filozofski fakultet Tuzla)

Prof. dr. sc. Tajana Krička - Hrvatska (Agronomski fakultet Zagreb)

Doc. dr. sc. Dejan Kojić - Bosna i Hercegovina (Univerzitet PIM)

Slobodan Kulić, mag. iur. - Srbija (Srpska ornitološka federacija i Confederation ornitologique mondiale)

Prof. dr. sc. Biljana Lazović - Crna Gora (Biotehnički fakultet Podgorica)

Doc. dr. sc. Zvonimir Marijanović - Republika Hrvatska (Kemijsko-tehnološki fakultet u Splitu)

Doc. dr. sc. Ana Matin - Hrvatska (Agronomski fakultet Zagreb)

Prof. dr. sc. Bosiljka Mustać - Hrvatska (Sveučilište u Zadru)

Hrv. akademik prof. dr. sc. Stanislav Nakić - Bosna i Hercegovina (Sveučilište Hercegovina Mostar)

Sandra Popović, mag. ing. - Srbija (Poljoprivredni fakultet Beograd)

Doc. dr. sc. Bojan Simovski - Sjeverna Makedonija (Šumarski fakultet Skopje)

Prof. dr. sc. Davor Skejić - Hrvatska (Građevinski fakultet Zagreb)

Doc. dr. sc. Milan Stanković - Srbija (Univerzitet u Kragujevcu)

Akademik prof. dr. sc. Refik Šećibović - Bosna i Hercegovina (Visoka škola za turizam i menadžment Konjic)

Prof. dr. sc. Andrej Šušek - Slovenija (Fakulteta za kmetijstvo in biosistemske vede Maribor)

Prof. dr. sc. Elma Temim - Bosna i Hercegovina (Agromediteranski fakultet Mostar)

Mr. sc. Merima Toromanović - Bosna i Hercegovina (Biotehnički fakultet Univerziteta u Bihaću)

Doc. dr. sc. Ivana Vitasović Kosić - Hrvatska (Agronomski fakultet Zagreb)

Doc. dr. sc. Ana Vujošević - Srbija (Poljoprivredni fakultet Beograd)

Prof. dr. sc. Vesna Židovec - Hrvatska (Agronomski fakultet Zagreb)

Lektura i grafička priprema: Ančica Sečan Matijaščić, mag. act. soc.

Objavljeno: 30. lipnja 2019. godine.

Časopis izlazi u elektroničkom izdanju dva puta godišnje, krajem lipnja i prosinca, a predviđena su i dva interdisciplinarna specijalna izdanja tijekom godine iz STEM i ostalih znanstvenih/umjetničkih područja.

Časopis je besplatan. Rukopisi i recenzije se ne vraćaju i ne honoriraju.

Umnožavanje (reproduciranje), stavljanje u promet (distribuiranje), priopćavanje javnosti, stavljanje na raspolaganje javnosti odnosno prerada u bilo kojem obliku nije dopuštena bez pismenog dopuštenja Nakladnika.

Sadržaj objavljen u Glasilu Future može se slobodno koristiti u osobne i obrazovne svrhe uz obvezno navođenje izvora. 


\section{Glasilo Future}

\section{Stručno-znanstveni časopis}

FUTURA - stručno-znanstvena udruga za promicanje održivog razvoja, kulture i međunarodne suradnje, Bana Josipa Jelačića 13 a, 22000 Šibenik, Hrvatska

(2019) $2(1-2) 01-76$

\section{SADRŽAJ:}

\section{Izvorni znanstveni rad (original scientific paper)}

Anarma Poprženović, Špela Pezdevšek Malovrh, B. Dorbić, E. Delić

Stavovi o društvenoj funkciji i općem stanju zelenila u Bihaću (Bosna i Hercegovina)

Attitudes on social function and overall status of greenery in the city of Bihać (Bosnia and

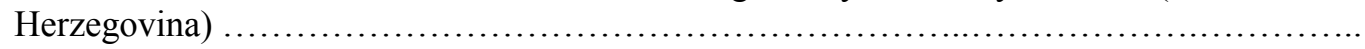

Aida Šukalić, Alma Rahimić, Vedrana Komlen, Alma Mičijević, Lamija Aliman

Sadržaj arsena u plodovima nektarine (Prunus persica var. nucipersica Schnied.) na području Hercegovine s procjenom rizika na zdravlje ljudi

The content of arsenic in nectarine fruit (Prunus persica var. nucipersica Schnied.) with risk assessment for human health on area of Herzegovina

Emilija Friganović, Martina Runje, Sara Ujaković, B. Dorbić, Mladenka Šarolić,

Duška Ćurić, Tajana Krička

Senzorska procjena tjestenine obogaćene proteinima konoplje i graška

Sensory evaluation of hemp and pea proteins enriched pasta

\section{Prethodno priopćenje (preliminary communication)}

B. Dorbić, Emilija Friganović, Marija Slipčević, Margarita Davitkovska, Zvezda Bogevska, Ana Vujošević

Senzorska procjena različitih oparaka od aromatičnog bilja

Sensory evaluation of different infusions from aromatic herbs

\section{Stručni rad (professional paper)}

Mladenka Šarolić, Josip Roguljić, Emilija Friganović, Žana Delić, Boris Dorbić, Marina

\section{Torić}

Poljički soparnik

"Poljički soparnik".

\section{Nekategorizirani rad (uncategorised paper)}

\section{S. Kulić}

Kanarinac pjesme slavujar (Song Canary "Slavujar")

Popularan rad

Popular paper

Zdenka Bilušić

Prikaz konferencije

Review of conference

\section{B. Dorbić}

Društvene vijesti i obavijesti

Social news and announcements 
B. Dorbić, Emilija Friganović, Marija Slipčević, Margarita Davitkovska, Zvezda Bogevska, Ana Vujošević / Senzorska procjena različitih oparaka od aromatičnog bilja / Glasilo Future (2019) 2 (1-2) 44-58

\title{
Senzorska procjena različitih oparaka od aromatičnog bilja
}

\section{Sensory evaluation of different infusions from aromatic herbs}

\author{
Boris Dorbić $^{1 *}$, Emilija Friganović ${ }^{1}$, Marija Slipčević ${ }^{1,2}$, Margarita Davitkovska ${ }^{3}$, \\ Zvezda Bogevska $^{3}$, Ana Vujošević ${ }^{4}$
}

prethodno priopćenje (preliminary communication)

doi: $10.32779 /$ gf.2.1-2.4

\section{Sažetak}

U prošlosti i sadašnjosti čovjek je bio okružen i ovisan o ljekovitom bilju. Postepeno ga je upoznavao i to prvo za liječenje, a kasnije i za prehranu. U preradi aromatičnog bilja uglavnom se koriste samo oni dijelovi biljke (npr. plod, cvijet, list, stabljika, korijen, gomolj itd.) koji sadrže aktivne tvari. Čaj se može prirediti kao oparak, uvarak, provarak i naljev. Uglavnom se većina čajeva pripravlja kao oparak ili infuzija. U općem dijelu rada su opisane biološke i kemijske karakteristike aromatičnog bilja čiji su oparci korišteni za senzorsku procjenu, a to su: lavanda, lipa, kamilica, paprena metvica (menta), komorač, kadulja i majčina dušica. U praktičnom dijelu rada metodom senzorske procijene potrošača obavljena je procjena oparaka od gore navedenih vrsta aromatičnog bilja (20 gramske filtarske monodoze) tvrtke Franck d.o.o. Zagreb, što je ujedno i cilj ovoga rada. Senzorska procjena je provedena tijekom druge polovice 2018. godine na uzorku od 20 studenata Veleučilišta "Marko Marulić" u Kninu. Rezultati procjene su pokazali sljedeće: ispitanici su ocjenom dovoljan ocijenili oparak od kadulje. Oparci od lavande, majčine dušice i lipe su ocijenjeni ocjenom dobar, a oparke od mente, kamilice i komorača ispitanici su ocijenili s ocjenom vrlo dobar.

Ključne riječi: aromatične vrste, aromatični oparci, senzorska procjena.
Abstract
Both in the past and in the present humans have been surrounded and dependent on medicinal herbs. They gradually gained a deeper insight into them, primarily for the purpose of use in traditional medicine and subsequently also in order to use in everyday diet. All the parts of the plant that contain active substances (e.g. fruit, flower, leaf, stem, root, tuber, etc.) are used in the processing of aromatic

\footnotetext{
${ }^{1}$ Veleučilište "Marko Marulić" u Kninu, Odjel Poljoprivreda krša i Odjel Prehrambena tehnologija, Krešimirova 30, 22300 Knin, Hrvatska.

*E-mail: bdorbic@veleknin.hr.

${ }^{2}$ Završena studentica preddiplomskog stručnog studija Prehrambena tehnologija.

${ }^{3}$ Univerzitet Sv. Kiril i Metodij Skopje, Fakultet za poljoprivredne znanosti i hranu Skopje, Katedra za Povrćarstvo i cvjećarstvo, Ul. 16 Makedonska brigada br. 3,1000 Skopje, Republika Makedonija.

${ }^{4}$ Poljoprivredni fakultet Univerziteta u Beogradu, Katedra za ratarstvo i povrtarstvo, Nemanjina 6, 11080 Beograd-Zemun, Republika Srbija.
} 
plants. Tea can be prepared as an infusion, decoction, extraction through cooking and maceration. Most teas are prepared as an infusion. The general part of the paper provides a description of biological and chemical characteristics of aromatic plants whose infusion had been used for sensory evaluation, such as: lavender, linden, chamomile, peppermint (mint), fennel, sage and thyme. In the practical segment of the paper, the method of consumer sensory evaluation was used to evaluate the infusions made from the previously mentioned species of aromatic plants (20 grams monodose) produced by the company Franck L.t.d. Zagreb, which was simultaneously also the objective of this paper. Sensory evaluation was conducted during the second half of 2018 on a sample of 20 students from Marko Marulić Polytechnic of Knin. According to the evaluation results, sage infusion was graded as sufficient by the respondents. Infusions from lavender, thyme and linden were graded as good, whereas infusions from mint, chamomile and fennel were graded as very good by the respondents.

Key words: aromatic species, aromatic infusions, sensory evaluation.

\section{Uvod}

Od ljudskog postojanja pa do danas čovjek je bio okružen i ovisan o ljekovitom bilju. Postepeno ga je upoznavao, prvo za liječenje, a onda i za prehranu (Kolak, 1997). Prvi znanstveni i dugoročni pristup za prikupljanje i proučavanje gen plazme ljekovitog i aromatičnog bilja dao je prof. dr. sc, Ivan Kolak u okviru Hrvatske banke biljnih gena (HBBG) (Kolak et al., 2002).

U zadnjem desetljeću bilježi se sve veći interes za proizvodnju, preradu, uporabu i trženje ljekovitog, aromatičnog i medonosnog bilja u Europi i kod nas (Kolak et al., 2002). Na našim prostorima se koristilo oko 170 autohtonih biljnih vrsti (Šilješ et al., 1992., prema Kolak et al., 1997).

Mnogobrojni proizvodi prehrambene industrije sadrže biološke aktivne tvari ljekovitog bilja (Pahlov, 1989). U praksi se često događa da su ljekovite biljke ujedno i aromatične jer sadrže jednu ili više aktivnih tvari posebnog mirisa (Kolak, 1997).

Pod pojmom fitoterapija danas se podrazumijeva liječenje i sprječavanje bolesti te različitih tegoba uz pomoć biljaka, biljnih dijelova i njihovih pripravaka. Biljni pripravci imaju široko terapijsko djelovanje. Fitoterapija nije alternativa današnjoj "konvencionalnoj"medicini, nego njezin dio koji ispunjava prazninu i nudi dodatne mogućnosti pri liječenju i sprečavanju različitih stanja bolesti (Paradžiković, 2013).

Čaj je pripravak koji se dobiva namakanjem određenih vrsta biljaka u vodi. Premda ima prednosti nad kavom, potrošnja mu je u Republici Hrvatskoj manja od potrošnja kave. Ovisno o načinu obrade sušenog lišća i lisnih pupoljaka biljke čajevac (Camellia sinensis) čaj može biti: crni, zeleni, oolong i dr. Osim potonje vrste (kamelija) u promet se mogu stavljati i "čajevi" pod nazivom aromatizirani čaj, 
B. Dorbić, Emilija Friganović, Marija Slipčević, Margarita Davitkovska, Zvezda Bogevska, Ana Vujošević / Senzorska procjena različitih oparaka od aromatičnog bilja / Glasilo Future (2019) 2(1-2) 44-58

dekofeinizirani čaj, biljni čaj, voćni čaj itd. (Tucakov, 1978; Matasović, 1997; Tadejevič i Jakovlić, 1976; Anonymous, 2000; Reto et al., 2007; Mitscher i Dolby, 1997, prema Perl Pirički et al., 2010).

Čaj se može pripraviti kao oparak, uvarak, provarak i naljev. Uglavnom se većina čajeva pripravlja kao oparak ili infuz. Za pripremu oparka ukoliko nije drugačije navedeno 1- 2 čajne žlice suhe, usitnjene biljke preliju se s 2,5 dl kipuće vode, promiješa se i poklopi te nakon 10 minuta čaj se procijedi. Ako se kod pripreme koristi svježa biljka, količinu je potrebno udvostručiti. Na ovaj način se pripravlja čaj od nježnih dijelova biljke (cvijet, list) ili kod onih koje sadrže termolabilne tvari (alkaloidi, antrakinonski glikozidi) ili kod onih koje sadržavaju lako hlapive tvari (eterično ulje). Toj grupi pripadaju: stolisnik, smilje, neven, menta, neven, breza itd. (Paradžiković, 2013).

U prehrambenoj industriji se uz pomoć znanstvene discipline koja se naziva "Senzorska procjena" uklanjaju ili primjećuju izvori grešaka u nekom proizvodu, pa se ona i primjenjuje kada se želi utvrditi najbolji postupak prerade, izbor sirovina, ispitati utjecaj zamjene jednog sastojka drugim itd. a sve sa ciljem bolje prihvatljivosti proizvoda kod potrošača (Koprivnjak, 2014). Navedena metoda će se koristiti u okviru ovog rada.

Cilj ovog rada bila je senzorska procjena različitih oparaka od aromatičnog bilja. U radu se također opisuju biološke i kemijske karakteristike odabranih vrsta aromatičnog bilja.

\section{Materijali i metode}

Tijekom izrade rada kao izvor primarnih podataka korištena je senzorska procjena oparaka aromatičnoga bilja, a za sekundarne podatke korišteni su različiti stručni i znanstveni radovi, knjige, itd.

Zavod za senzorsku procjenu Instituta za prehrambenu tehnologiju USA, senzorsku procjenu definira kao znanstvenu disciplinu koja potiče, mjeri, analizira i interpretira reakcije karakteristike hrane i tvari koje se zapažaju osjetilima: vida, mirisa, okusa, dodira i sluha (Vahčić, 2013).

Senzorsku procjenu oparaka od aromatičnog bilja izvršili su studenti Veleučilišta "Marko Marulić" u Kninu (n = 20). U navedeno ispitivanje procjene bili su uključeni studenti druge godine stručnog preddiplomskog studija Poljoprivreda krša - Biljna proizvodnja i studenti druge i treće godine stručnog preddiplomskog studija Prehrambena tehnologija. Odabrani su sljedeći čajevi (20 gramske monodoze) tvrtke Franck d.o.o. Zagreb: lavanda (Uzorak 1.), kadulja (Uzorak 2.), majčina dušica (Uzorak 3.), menta (Uzorak 4.), lipa (Uzorak 5.), kamilica (Uzorak 6.) i komorač (Uzorak 7.). Uzorci čaja od aromatičnog bilja pripremljeni su prema unaprijed odabranim i ispitanim recepturama. Dvije filtar vrećice biljnog čaja (ukupno $40 \mathrm{~g}$ ) su prelivene s 1 L kipuće vode i ostavljene u staklenoj posudi 3 minute da se dobije čajni oparak. 
B. Dorbić, Emilija Friganović, Marija Slipčević, Margarita Davitkovska, Zvezda Bogevska, Ana Vujošević / Senzorska procjena različitih oparaka od aromatičnog bilja / Glasilo Future (2019) 2(1-2) 44-58

Uzorci su pripremani u jednoj koncentraciji s ponuđenim jednim uzorkom te nisu bili zaslađeni. Topli uzorci bili su pripremljeni neposredno prije testiranja i "potrošačima" servirani u malim plastičnim čašicama kodiranim jednoznamenkastim brojevima $(1-7)$. Ispitanici nisu znali o kojoj se vrsti čaja radi. Senzorska procjena je provedena na Veleučilištu "Marko Marulić" u Kninu, a vodila ga je trenirana osoba.

Cilj senzorske procjene bio je izvršiti senzorsku procjenu oparaka od aromatičnog bilja. Na ocjenjivačkom listiću ispitivač je morao za svaki uzorak ocijeniti parametar boje, okusa, mirisa, te opći dojam na način da upiše plus u kvadratić koji odgovara pojedinoj ocjeni. Raspon ocjena bio je od 1 do 5; gdje 1 odgovara najnižoj ocjeni, a 5 najvišoj.

Biološke i kemijske karakteristike odabranih vrsta aromatičnog bilja

Lavanda (Lavandula officinalis Mill.)

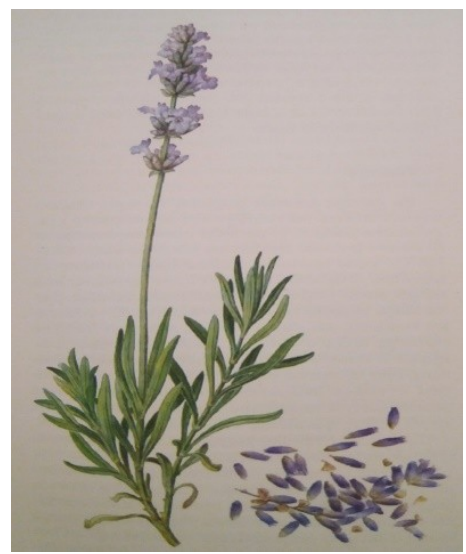

Slika 1. Lavanda (Lavandula officinalis Mill.) (Kišgeci, 2008).

Figure 1. Lavender (Lavandula officinalis Mill.) (Kišgeci, 2008).

\section{Biološke karakteristike}

U rodu Lavandula (Slika 1.) ima oko 48 vrsta. Samo tri vrste ovog roda lavande imaju veći gospodarski značaj, od kojih je najpoznatija i najduže uzgajana prava lavanda (medicinska, mirisna, uskolisna), L. Angustifolia Mill. Druga je zatim, širokolisna (muška), L. Latifolia Medic. Veliki značaj ima i hibridna lavanda (engleska, lavandin), L. Intermedia Emeric ap. Lois. koja je spontani hibrid od potonje dvije vrste. Sve tri vrste dolaze iz Sredozemlja, iz južne Europe (Kišgeci, 2008).

Lavanda (Lavandula officinalis Mill.) je višegodišnji polugrm. Korijenov sustav je odrvenjen i gusto razgranat koji penetrira i do 3-4 m u dubinu. Stabljika joj je gusto razgranata i prekrivena smeđom bojom. U prirodnim uvjetima grm lavande je u obliku polugrma. Visina grma prave lavande je $40-60$ $\mathrm{cm}$, a hibridne $80-100 \mathrm{~cm}$. Prava lavanda ima cvjetne grane koje su duge $20-40 \mathrm{~cm}$, nerazgranate su, a kod hibridne lavande su duge $60-90 \mathrm{~cm}$ i razgranate. Listovi prave lavande su izduženo 
kopljasti, nasuprotni i dugi $3-5 \mathrm{~cm}$, a široki $0,2-0,5 \mathrm{~cm}$, sivozelene i dlakavi. Listovi hibridne lavande su veći za nekoliko centimetara i $0,8-1 \mathrm{~cm}$ široki. Slabije su dlakavi i tamnozelene boje (Kišgeci, 2008).

Modri cvjetovi nalaze se na vrhu grančica, a skupljeni su u cvatove nalik klasu. Cijela biljka ima karakterističan miris, dok je okus herbe malo gorak (Willfort, 2002).

Plod je merikarp građen četiri jedno sjemena plodića. Plodić je dugačak 1,8-2,2 mm, jajastog je oblika, tamne boje i sjajan. Sjeme hibridne lavande je sterilna. Lavanda je dugovječna biljka, koja može živjeti 20 - 30 godina. Prava lavanda počinje cvjetati sredinom lipnja, a završava krajem srpnja. Hibridna lavanda uglavnom cvjeta kasnije i to prvoj polovici srpnja. Puno cvjetanje traje $6-8$ dana, i tada je zabilježena najveća količina i kvaliteta eteričnog ulja (Kišgeci, 2008).

\section{Kemijska svojstva}

Eteričnog ulja u cvjetovima lavande ima u količini 0,5 - 1,5 \%, dok ga je kod hibridne nešto više $0,9-3 \%$. Ulje se dobiva destilacijom svježih cvjetova uz pomoć vodene pare. To je bezbojna (svijetlo žuta) tekućina s ugodnim mirisom te ljutim i gorkim okusom. Glavne aktivne tvari eteričnog ulja lavande su 1-linaliacetat i 1-linalol (Kišgeci, 2008). Cvijet sadrži 1 do $3 \%$ eteričnoga ulja (linalilacetata, linaloola, cineola, kamfora), treslovine (5 do $10 \%$ ), kumarin, flavonoide, sterole, gorke tvari (Opletal i Volak, 2001). Lavanda ima sposobnost umirivanja grčeva te lagano nadražujuće i osvježavajuće djelovanje. Koristi se kod nadutosti, migrene, vrtoglavice i dr., te se konzumira kao čajni oparak ili za vanjsku upotrebu (Willfort, 1974).

Lavanda se najviše upotrebljava u kozmetičkoj industriji (Kišgeci, 2008).

\section{Lipa (Tilia spp.)}

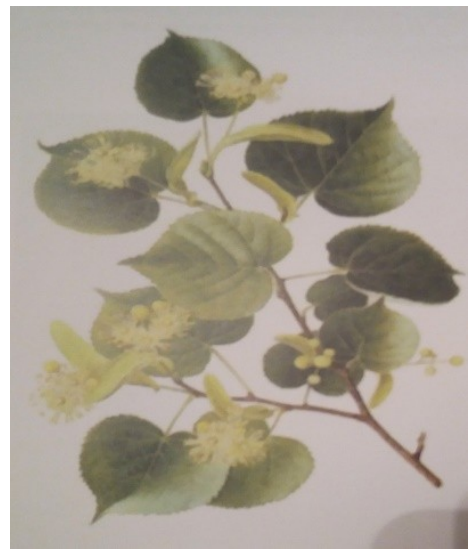

Slika 2. Lipa (Tilia spp.) (Kišgeci, 2008).

Figure 2. Linden (Tilia spp.) (Kišgeci, 2008). 
B. Dorbić, Emilija Friganović, Marija Slipčević, Margarita Davitkovska, Zvezda Bogevska, Ana Vujošević / Senzorska procjena različitih oparaka od aromatičnog bilja / Glasilo Future (2019) 2(1-2) 44-58

\section{Biološke karakteristike}

Lipa (Tilia spp.) raste u šumama, zelenim površinama, parkovima i drvoredima uz cestu ruralnih i gradskih krajobraza (Gursky, 1999). Neke vrste lipa rastu u spontanoj flori na području Hrvatske (Slika 2.), ali se najviše koriste Tilia cordata Mili. (sitnolisna lipa) i Tilia platyphyllos Scop. (krupnolisna lipa). Krupnolisna lipa je visoko drvo s širokom i gustom krošnjom. Listovi su spiralno raspoređeni, srcolikog su oblika, veliki, na vrhu zašiljeni i otpadaju u jesen. List krupnolisne lipe je dlakav (s obje strane), a s naličja je bljeđi i u kutovima neravan s karakterističnim bijelim čupercima. List sitnolisne lipe je manji, na licu je tamnozelene boje i gladak, a s naličja je svijetlozelen i u kutovima neravan sa karakterističnim smeđim dlačicama. Cvjetovi su dvospolni i pravilni. Kod sitnolisne lipe cvjetovi su aktinomorfni, dolaze od 5 - 15 zajedno, a kod krupnolisne lipe su nešto krupniji i grupirani obično po 3 zajedno. Cvjeta u lipnju i srpnju, dok krupnolisna lipa cvjeta dvije nedjelje prije sitnolisne. Lipe su odlične medonosne vrste. Plod je složeni oraščić (Kišgeci, 2008).

\section{Kemijska svojstva}

Cvijet lipe ima oko $0,02 \%$ eteričnoga ulja s mirisnim komponentama: farnezolom, (farnezilacetatom i geraniolom), $1 \%$ flavonolskih glikozida i oko $2 \%$ treslovina, sluzi i mineralne soli (Gursky, 1999). Lipa se koristi najčešće u svrhu pripreme čajnog oparka i to kod raznih prehlada i infektivnih oboljenja dišnih organa, prilikom pojačanog znojenja, protiv grčeva i za ublažavanje bolova (Kišgeci, 2008).

\section{Kamilica (Matricaria Chamomilla L.)}

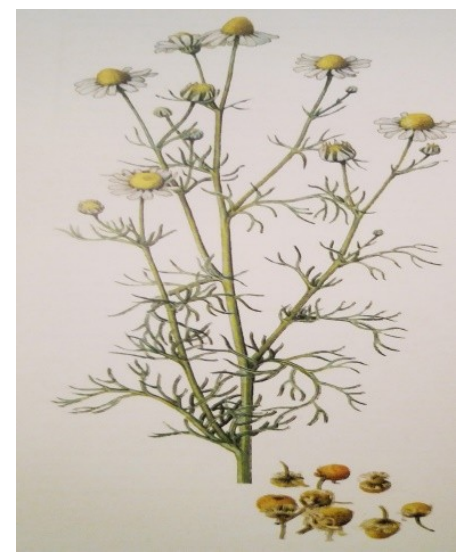

Slika 3. Kamilica (Matricaria Chamomilla L.) (Kišgeci, 2008).

Figure 3. Chamomile (Matricaria Chamomilla L.) (Kišgeci, 2008).

\section{Biološke karakteristike}

Slika 3. prikazuje kamilicu (Matricaria Chamomilla L.) koja raste u blizini naselja, te napuštenim zemljištima. Uzgaja se u vrtovima i na plantažama (Zovkić, 1999). 
B. Dorbić, Emilija Friganović, Marija Slipčević, Margarita Davitkovska, Zvezda Bogevska, Ana Vujošević / Senzorska procjena različitih oparaka od aromatičnog bilja / Glasilo Future (2019) 2(1-2) 44-58

Jednogodišnja je zeljasta kultivirana vrsta i visoka do $80 \mathrm{~cm}$. Korijen joj je tanak, slabo razvijen i vretenast. Stabljika je uspravna, valjkasta i razgranata. Listovi su višestruko perasto razdijeljeni. Cvjetovi su joj skupljeni u glavicu (promjera 1,5-3 cm). Ženski jezičasti bijeli cvjetovi se nalaze po obodu, a u sredini se nalaze dvospolni, cjevasti cvjetovi žute boje. Cvjetište je šuplje i malenog oblika. Cvjetovi imaju karakterističan opojni miris. Plod je sivo bijele boje, dužine do 1,2 mm, širine 0,4 mm, a jednom kilogramu ima preko 20 miliona sjemenki (Kišgeci, 2008).

Kamilica cvate od svibnja do kolovoza i prikupljaju se samo cvjetne glavice u lipnju i srpnju. Suše se u hladu i na propuhu. Za pripravu kupelj ili kupke sabire se cijela biljka (Zovkić, 1999).

\section{Kemijska svojstva}

Kod kamilice se koriste cvjetna glavica (Chamomillae flos) i eterično ulje (Chamomillae aetheroleum). Cvjetne glavice sadrže više od $1 \%$ eteričnoga ulja i različite aktivne tvari: gorke tvari, tanine, smole, flavonoide, kumarine, organske kiseline i dr. Destilacijom pomoću vodene pare dobiva se eterično ulje kamilice. Ulje je gusto te je na nižim temperaturama smolasto. Zelene je do tamnoplave boje s karakterističnim mirisom i gorkim okusom. Glavni sastojci ulja su: hamazulen (4 - $21 \%$ ), alfabisabolo, bisabolo oksidi, franezen i dr. Ukoliko se eterično ulje dobiva estrakcijom droge tada ne sadrži hamazulen i žute je boje. Ovisno o kultivaru variraju količine i sastav eteričnog ulja (Kišgeci, 2008).

Kamilica je jedno od najboljih ljekovitih sredstava za žene i djecu. Njezino je svojstvo da umiruje te da stišava bolove i grčeve. Ona je vrlo dobra kao sredstvo za bolesti želuca i crijeva (grčevi u želucu, upala debelog crijeva, za ublažavanje proljeva i dr.) (Willfort, 1974).

\section{Paprena metvica, menta (Mentha x piperita)}

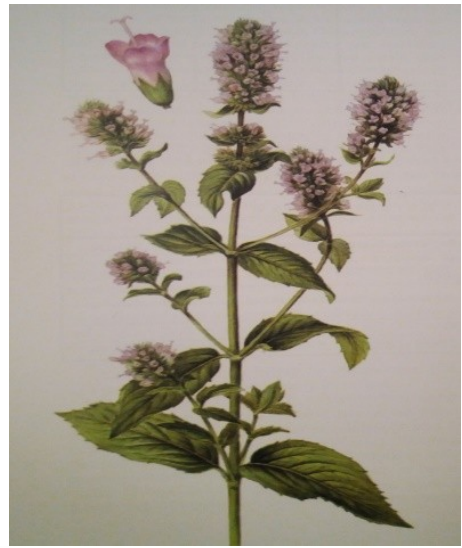

Slika 4. Paprena metvica (menta) (Mentha x piperita) (Kišgeci, 2008).

Figure 4. Peppermint (mint) (Mentha x piperita) (Kišgeci, 2008). 
B. Dorbić, Emilija Friganović, Marija Slipčević, Margarita Davitkovska, Zvezda Bogevska, Ana Vujošević / Senzorska procjena različitih oparaka od aromatičnog bilja / Glasilo Future (2019) 2(1-2) 44-58

\section{Biološke karakteristike}

Menta (Mentha x piperita) je prikazana na Slici 4. Ona je kultivirana biljka. Stabljika joj je uspravna, kao grana, a visina iznosi 30 do $70 \mathrm{~cm}$ i bridasta je. Listovi su s peteljkom, nazubljeni i šiljasti, a cvjetovi se nalaze u izduženim klasovima na vrhovima grančica (Kremer, 2007). Cvjetovi su ljubičasti, rijetko bijeli. Plod je sastavljen iz četiri dijela (sa jednom sjemenkom) (Kišgeci, 2008).

Cvate od lipnja do kolovoza te se sakuplja prije cvatnje. Koriste se listovi, ali i mladice s cvjetnim vrhovima. Lišće joj ima ugodan okus i aromatičan mirisi (Gursky, 1999).

Biljka je sterilna i razmnožava se vegetativnim putem. List, nadzemni dijelovi biljke i eterično ulje u farmaciji se koriste za pripravu kozmetičkih preparata, parfema, zubnih pasta i dr. Menta je često korišteni začin koji se koristi za poboljšavanje i popravke okusa pića i slatkih proizvoda (Kišgeci, 2008).

\section{Kemijska svojstva}

Eterično ulje mente je intenzivnog mirisa, a sadrži mentol, menton, cineol i nekoliko drugih tvari. Listovi su najčešće korištena čajna droga. Oparak se priprema da se 2 čajne žličice/šalici ostavi da odstoji najviše 5 minuta, to je sredstvo za poticanje metabolizma, umanjenje grčeva, i probavnih problema (Kremer, 2007).

Ljekovito djelovanje ove vrste potječe od eteričnog ulja, kojeg ima oko $1-1,5 \%$ (u cijeloj biljci). U listovima ga ima 1,5 do 3,5\%, tj. prosječno $2 \%$. Mentol je glavni sastojak eteričnog ulja, kojega ima oko $50 \%$ i 15 - $25 \%$ mentona. Dobiva se destilacijom uz pomoć vodene pare iz nadzemnih dijelova biljke. Ulje je bistra, žućkasta, viskozna tekućina, ugodnog mirisa na mentol i osvježavajućeg ukusa. Upotrebljava se kao ugodan, blag i neškodljiv lijek za umirivanje, protiv nadutosti, grčeva i dr. (Kišgeci, 2008).

Komorač (Foeniculum vulgare Mill.)

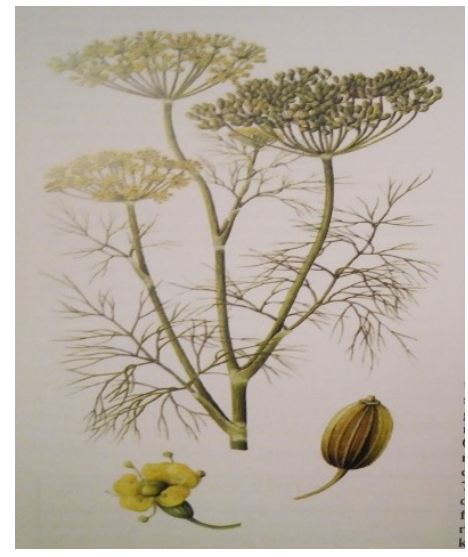

Slika 5. Komorač (Foeniculum vulgare Mill.) (Kišgeci, 2008).

Figure 5. Fennel (Foeniculum vulgare Mill.) (Kišgeci, 2008). 
B. Dorbić, Emilija Friganović, Marija Slipčević, Margarita Davitkovska, Zvezda Bogevska, Ana Vujošević / Senzorska procjena različitih oparaka od aromatičnog bilja / Glasilo Future (2019) 2(1-2) 44-58

\section{Biološke karakteristike}

Slika 5. prikazuje komorač (Foeniculum vulgare Mill.) koji raste po kamenjarima Hrvatskog primorja, Dalmacije i Makedonije. Biljka se može pronaći uz rubove polja i putova, a uzgaja se i u vrtovima. Komorač je 80 - $120 \mathrm{~cm}$ visoka biljka, s šupljom i razgranatom stabljikom. Listovi su perasti i duboko urezani. U štitcima se nalaze mali, zlatnožuti cvjetovi (Gursky, 1999).

Cvjetovi su sitni, mirisni, žute boje, a skupljeni su u cvat. Cvatovi su združeni u guste i složene štitove koji su smješteni na vrhu stabljike i ogranaka. Komorač ima dugo razdoblje cvatnje, od srpnja do listopada. Neravnomjerno cvjetanje uvjetuje i neujednačeno sazrijevanje ploda, iz kojeg se izdvaja ulje. Plod je sastavljen od dvije sjemenke, sive do žutozelene boje, dužine oko $10 \mathrm{~mm}$ i širine oko 4 mm. On se lako raspada na dva merikarpa. Masa 1000 sjemenki iznosi $4-8$ g. Klijavost sjemena je dosta visoka, 90 - 100 \% (Kišgeci, 2008).

\section{Kemijska svojstva}

Komorač se uzgaja uglavnom radi ploda koji sadrži i 2 - $6 \%$ eteričnog ulja, čija je glavna aktivna tvar anetol. Plod sadrži oko 18 \% masnog ulja, 5 \% šećera, oko $20 \%$ bjelančevina itd. Eterično ulje mu je bezbojno, svjetlo žućkaste boje, ugodnog i blagog mirisa. Okus ulja je sladak, a potom i pomalo gorak. Ulje sadrži: oko 70 \% anetola, 20 \% (i više) fenhona, alfa-pinen, limonen, dipenten (Kišgeci, 2008).

Eterično ulje s anetolom i fenhonom rastjeruje "vjetrove", također potiče izlučivanje mokraće te pospješuje iskašljavanje. Biljka se zbog toga koristi za umanjenje tegoba probavnih organa, ali i kod kašlja i bronhitisa (posebno kod male djece). Oparak se priprema na sljedeći način i to da se 1-2 čajne Žlice usitnjenih plodova/šalici te ostavi da odstoji 10 min (Kremer, 2007).

\section{Kadulja (Salvia officinalis L.)}

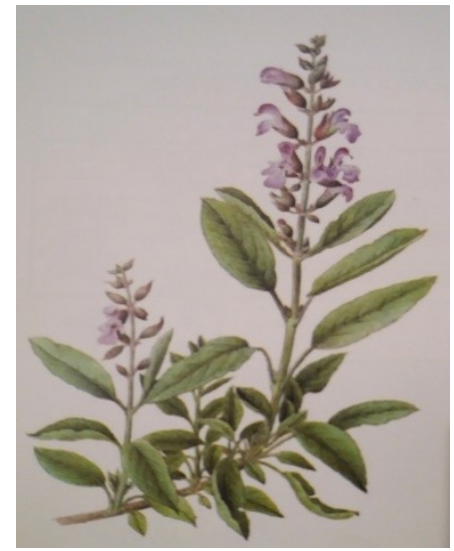

Slika 6. Kadulja (Salvia officinalis L.) (Kišgeci, 2008).

Figure 6. Sage (Salvia officinalis L.) (Kišgeci, 2008). 
B. Dorbić, Emilija Friganović, Marija Slipčević, Margarita Davitkovska, Zvezda Bogevska, Ana Vujošević / Senzorska procjena različitih oparaka od aromatičnog bilja / Glasilo Future (2019) 2(1-2) 44-58

\section{Biološke karakteristike}

Kadulja (Salvia officinalis L.) (Slika 6.) je autohtona ljekovita biljka Hrvatske. Kadulja je višegodišnja razgranata biljka, visoka je $50-90 \mathrm{~cm}$. Stabljika je dijelom odrvenjela i četverokutna na poprečnom presjeku. Listovi su izduženo lancetasti, zašiljeni na vrhu, nasuprotni, srebrnozeleni, sitno naborani, uski, s dugom peteljkom (Kišgeci, 2008). Cvjetovi su ljubičasti, na vrhovima stabljike tvore pršljenove. Svi dijelovi biljke (list, cvijet i stabljika) imaju jak, aromatičan i ugodan miris, koji se niti sušenjem ne gubi. Kadulja cvate od svibnja. Sakupljaju se listovi i stabljika prije cvatnje, tj. dok biljka nije potpuno procvala. Kadulja je jedna od najstarijih ljekovitih biljaka (Zovkić, 1999).

\section{Kemijska svojstva}

Koristi se list i eterično ulje, a u nadzemnom dijelu kadulje ima $1-2,5 \%$ eteričnog ulja i to najviše u listu. Eterično ulje se dobiva destilacijom pomoću vodene pare iz osušenih zeljastih dijelova biljke. Eterično ulje kadulje je bistro, žućkasto-zelene boje, aromatičnog mirisa i okusa koje donekle pecka (Kišgeci, 2008). Sastavnice ulja su: tujon, cineol, barneol, kanfor, tanin, glikozidi, smole i gorke tvari itd (Kolak et al., 2003). Koristi se kod probavnih smetnji, nedovoljnog lučenja želučane kiseline, problema s anoreksijom, infekcijom probavnih organa. Vodeni i akoholni ekstrakti od kadulje smanjuju pretjerano znojenje (Opletal i Volak, 2001).

Majčina dušica (Thymus serpyllum L.)

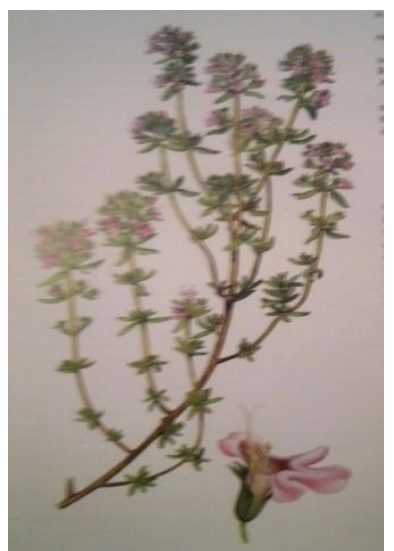

Slika 7. Majčina dušica (Thymus serpyllum L.) (Kišgeci, 2008).

Figure 7. Thyme (Thymus serpyllum L.) (Kišgeci, 2008).

\section{Biološke karakteristike}

Majčina dušica (Thymus serpyllum L.) je trajnica koja doseže $40 \mathrm{~cm}$ visine, grmolikog je oblika (Slika 7.). Ima sitne eliptične sivo-zelene listove. Cvjetovi su sitni ljubičasti ili bijeli sakupljeni u grozdovima i nalaze se na vrhovima stabljike. Plod je sitan, smeđe je boje (Kolak et al., 2003). 
B. Dorbić, Emilija Friganović, Marija Slipčević, Margarita Davitkovska, Zvezda Bogevska, Ana Vujošević / Senzorska procjena različitih oparaka od aromatičnog bilja / Glasilo Future (2019) 2(1-2) 44-58

Grančice su jako razgranjene, uspravne ili puzajuće, bridaste i dlakave (Kremer, 2007). Svijetlo crveni do tamno grimizni mali cvjetovi razvijaju se na vrhovima ogranaka, a skupljeni su u okruglastim cvatovima. Okus i miris majčine dušice nalikuje limunu i posjeduje lagano gorak okus. Alpski oblici majčine dušice imaju jači miris i trajniji okus pa su zasigurno od važnijeg ljekovitog djelovanja. Biljka cvate od sredine svibnja do sredine rujna (Willfort, 1974).

\section{Kemijska svojstva}

Eteričnog ulja u biljci ima $0,1 \%$ do $0,6 \%$, kao i sljedeće aktivne tvari: timol, karvakrol, p-cimol, linalool, cineol itd. Sastav eteričnoga ulja uvelike se razlikuje s obzirom na vrstu i staništa. Biljka sadrži i treslovine (do 7,5 \%), gorke tvari (serpilin), flavonoide (lutelin, apigenin itd.), te male količine saponina (Opletal i Volak, 2001). Eterično ulje opušta grčeve. U svrhu liječenja upotrebljava se za umanjenje tegoba kod kašlja i kroničnog bronhitisa, te probavnih tegoba (Kremer, 2007).

\section{Rezultati i diskusija}

\section{Senzorska procjena oparaka aromatičnog bilja}

U sljedećim tablicama $(1-7$.$) prikazani su rezultati senzorske analize oparaka različitih vrsta$ aromatičnog bilja. Za svaki uzorak ispitivač je trebao ocijeniti sljedeće karakteristike: boju, okus, miris, te opći dojam. Kod svakog uzorka za čajni oparak izračunata je aritmetička sredina, standardna devijacija i varijanca.

Tablica 1. Procjena uzorka oparka od lavande (prema Slipčević, 2018).

Table 1. Sample evaluation infusion of lavender (according to, Slipčević, 2018).

\begin{tabular}{|l|l|l|l|l|}
\hline Redni broj & Parametar ocjenjivanja & Aritm. Sredina & Stand. devijacija & Varijanca \\
\hline 1. & BOJA & 3,40 & 1,041 & 1,083 \\
\hline 2. & OKUS & 2,60 & 1,190 & 1,417 \\
\hline 3. & MIRIS & 2,96 & 1,241 & 1,540 \\
\hline 4. & OPĆI DOJAM & $\underline{\mathbf{2 , 8 4}}$ & 1,108 & 1,223 \\
\hline
\end{tabular}

Sukladno Tablici 1. ispitanici su ocijenili oparak od lavande dobrim ocjenama u rasponu od $(2,60-3,40)$. Najveća ocjena je dodijeljena boji oparka $(3,40)$, a najmanja okusu istog $(2,60)$. okus bio najlošije ocijenjen, što je vjerojatno utjecalo i na opći dojam napitka. Čaj od lavande je donekle nov na našem tržištu i vjerojatno ga potrošači slabije konzumiraju, ima izrazito "intenzivan" okus, a i lavanda se kod nas tradicijski koristi u druge namjene. Slično navedenom za konzumaciju čaja od peršina navodi i Perl Pirički et al., 2010. 
B. Dorbić, Emilija Friganović, Marija Slipčević, Margarita Davitkovska, Zvezda Bogevska, Ana Vujošević / Senzorska procjena različitih oparaka od aromatičnog bilja / Glasilo Future (2019) 2(1-2) 44-58

Tablica 2. Procjena uzorka oparka od kadulje (prema Slipčević, 2018).

Table 2. Sample evaluation infusion of sage (according to, Slipčević, 2018).

\begin{tabular}{|l|l|l|l|l|}
\hline Redni broj & Parametar ocjenjivanja & Aritm. Sredina & Stand. devijacija & Varijanca \\
\hline 1. & BOJA & 3,20 & 1,500 & 2,250 \\
\hline 2. & OKUS & 2,28 & 1,021 & 1,043 \\
\hline 3. & MIRIS & 2,32 & 1,030 & 1,080 \\
\hline 4. & OPĆI DOJAM & $\underline{\mathbf{2 , 4 0}}$ & 1,000 & 1,000 \\
\hline
\end{tabular}

Shodno Tablici 2. ispitanici su ocijenili oparak od kadulje uglavnom dovoljnim ocjenama. Najveća ocjena je dodijeljena boji oparka $(3,20)$, a najmanja okusu istog $(2,60)$, koji je vrlo intenzivan. Možda bi ovaj čaj u nešto slabijoj koncentraciji bio ispitanicima prihvatljiviji. Slične rezultate o koncentracijama kod nekih karakterističnih čajeva iznose i drugi autori kao npr. Vickers i Holton, 1998.

Tablica 3. Procjena uzorka oparka od majčine dušice (prema Slipčević, 2018).

Table 3. Sample evaluation infusion of thyme (according to, Slipčević, 2018).

\begin{tabular}{|l|l|l|l|l|}
\hline Redni broj & Parametar ocjenjivanja & Aritm. Sredina & Stand. devijacija & Varijanca \\
\hline 1. & BOJA & 3,56 & 1,193 & 1,423 \\
\hline 2. & OKUS & 3,28 & 1,100 & 1,210 \\
\hline 3. & MIRIS & 3,16 & 1,281 & 1,640 \\
\hline 4. & OPĆI DOJAM & $\underline{\mathbf{3 , 5 2}}$ & 1,085 & 1,177 \\
\hline
\end{tabular}

Kao što se vidi iz Tablice 3. ispitanici su ocijenili oparak od majčine dušice dobrim i vrlo dobrim ocjenama u rasponu od $(3,16$ - 3,56). Najveća ocjena je dodijeljena boji oparka $(3,56)$, a najmanja mirisu istog $(3,16)$. I ovaj se "čajni" oparak tradicijski kod nas vrlo malo konzumira i vjerojatno zbog toga nije dobio visoke ocjene. Čaj od majčine dušice ima pomalo gorak okus te je možda i to razlog zašto nije dobio veće ocjene (Willfort, 1974).

Tablica 4. Procjena uzorka oparka od mente (prema Slipčević, 2018).

Table 4. Sample evaluation infusion of peppermint (mint) (according to, Slipčević, 2018).

\begin{tabular}{|l|l|l|l|l|}
\hline Redni broj & Parametar ocjenjivanja & Aritm. Sredina & Stand. devijacija & Varijanca \\
\hline 1. & BOJA & 3,52 & 1,046 & 1,093 \\
\hline 2. & OKUS & 3,84 & 1,143 & 1,307 \\
\hline 3. & MIRIS & 4,04 &, 978 &, 957 \\
\hline 4. & OPĆI DOJAM & $\underline{\mathbf{3 , 6 8}}$ & 1,145 & 1,310 \\
\hline
\end{tabular}

Iz Tablice 4. je razvidno da su ispitanici ocijenili oparak od mente vrlo dobrim ocjenama u rasponu od $(3,52-4,04)$. Najveća ocjena je dodijeljena okusu oparka $(3,84)$, a najmanja boji istog $(3,52)$. Oparak od mente je u pogledu osjetilnih karakteristika u odnosu na gore navedene oparke postigao zbog manje izražene gorčine i trpkosti. Slične rezultate iznosi i Komes et al., 2017, kod dodavanja mentinog ekstrakta u kozje mlijeko. 
B. Dorbić, Emilija Friganović, Marija Slipčević, Margarita Davitkovska, Zvezda Bogevska, Ana Vujošević / Senzorska procjena različitih oparaka od aromatičnog bilja / Glasilo Future (2019) 2(1-2) 44-58

Tablica 5. Procjena uzorka oparka od lipe (prema Slipčević, 2018).

Table 5. Sample evaluation infusion of linden (according to, Slipčević, 2018).

\begin{tabular}{|l|l|l|l|l|}
\hline Redni broj & Parametar ocjenjivanja & Aritm. Sredina & Stand. devijacija & Varijanca \\
\hline 1. & BOJA & 2,88 & 1,333 & 1,777 \\
\hline 2. & OKUS & 2,84 & 1,313 & 1,723 \\
\hline 3. & MIRIS & 2,84 & 1,434 & 2,057 \\
\hline 4. & OPĆI DOJAM & $\underline{\mathbf{3 , 1 6}}$ & 1,463 & 2,140 \\
\hline
\end{tabular}

Sukladno Tablici 5. ispitanici su ocijenili oparak od lipe dobrim ocjenama u rasponu od $(2,84-3,16)$. Najveća ocjena je dodijeljena općem dojmu $(3,16)$, a najmanja okusu i mirisu istog $(2,84)$. Oparak je bio nezašećeren i nije imao dovoljan intenzitet, pa su mu vjerojatno zbog toga ispitanici dali manju ocjenu. Kod nas se lipov čaj tradicionalno pije dobro zaslađen s šećerom ili livadnim medom.

Tablica 6. Procjena uzorka oparka od kamilice (prema Slipčević, 2018).

Table 6. Sample evaluation infusion of chamomile (according to, Slipčević, 2018).

\begin{tabular}{|l|l|l|l|l|}
\hline Redni broj & Parametar ocjenjivanja & Aritm. Sredina & Stand. devijacija & Varijanca \\
\hline 1. & BOJA & 3,64 & 1,186 & 1,407 \\
\hline 2. & OKUS & 4,24 &, 723 &, 523 \\
\hline 3. & MIRIS & 4,12 & 1,054 & 1,110 \\
\hline 4. & OPĆI DOJAM & $\underline{\mathbf{3 , 8 8}}$ & 1,054 & 1,110 \\
\hline
\end{tabular}

Shodno Tablici 6. ispitanici su ocijenili oparak od kamilice vrlo dobrim ocjenama u rasponu od $(3,64-4,24)$. Najveća ocjena je dodijeljena okusu oparka $(4,24)$, a najmanja boji istog $(3,64)$. Oparak je bio ne zašećeren i nije imao dovoljan intenzitet, pa su mu vjerojatno zbog toga ispitanici dali manju ocjenu. "Potrošači-ispitanici, najvjerojatnije nemaju naviku konzumirati ne zaslađeni oparak od kamilice. Zbog svog blagog i ugodnog okusa te ljekovitosti (Willfort, 1974). kamilica se često koristi u ranijoj životnoj dobi i djetinjstvu i zbog toga je omiljeni napitak kod mlađe populacije.

Tablica 7. Procjena uzorka oparka od komorača (prema Slipčević, 2018).

Table 7. Sample evaluation infusion of fennel (according to, Slipčević, 2018).

\begin{tabular}{|l|l|l|l|l|}
\hline Redni broj & Parametar ocjenjivanja & Aritm. Sredina & Stand. devijacija & Varijanca \\
\hline 1. & BOJA & 3,84 & 1,214 & 1,473 \\
\hline 2. & OKUS & 3,72 & 1,021 & 1,043 \\
\hline 3. & MIRIS & 3,96 & 1,241 & 1,540 \\
\hline 4. & OPĆI DOJAM & $\underline{\mathbf{3 , 6 8}}$ & 1,069 & 1,143 \\
\hline
\end{tabular}

Prema Tablici 7. uočljivo je da su ispitanici su ocijenili oparak od komorača vrlo dobrim ocjenama u rasponu od $(3,68-3,96)$. Najveća ocjena je dodijeljena mirisu oparka $(3,96)$, a najmanja općem dojmu $(3,68)$. Kod nas se u narodu čaj od koromača najviše koristi u medicinske svrhe, za dojenčad i kod ublažavanja trbušnih problema (Kremer, 2007).

\section{Zaključak}

Na temelju senzorske procijene oparaka aromatičnoga bilja došlo se do sljedećih spoznaja: 
B. Dorbić, Emilija Friganović, Marija Slipčević, Margarita Davitkovska, Zvezda Bogevska, Ana Vujošević / Senzorska procjena različitih oparaka od aromatičnog bilja / Glasilo Future (2019) 2(1-2) 44-58

- $\quad$ ispitanici su ocjenom dovoljan ocijenili oparak od kadulje, u čijem slučaju je jedino boja dobila ocjenu dobar, ima izrazito "intenzivan" okus koji je pomalo i gorak;

- $\quad$ oparci od lavande, majčine dušice i lipe su ocijenjeni ocjenom dobar. Tako je, primjerice, kod oparka od lavande okus bio najlošije ocijenjen (lavanda se kod nas tradicijski uglavnom ne koristi za čajni napitak). Oparak od lipe u ovom slučaju nije bio zašećeren i nije imao dovoljan intenzitet okusa, pa su mu vjerojatno zbog toga ispitanici dali i manju ocjenu;

- $\quad$ oparke od mente, kamilice i komorača ispitanici su ocijenili s ocjenom vrlo dobar. Kamilica u nezašećerenom stanju ima nedovoljan intenzitet pa vjerojatno vrijedi konstatacija kao i za oparak od lipe.

\section{Zahvala}

Rad je izrađen u okviru izrade Završnog rada Marije Slipčević, bacc. ing. preh. teh. (vidi Literaturu).

\section{Literatura}

Anonymous (2000). Hrvatska enciklopedija 2. Zagreb: Leksikografski zavod Miroslav Krleža.

Gursky, Z. (1999). Zlatna knjiga ljekovitog bilja. Zagreb: Nakladni zavod matice Hrvatske.

Kišgeci, J. (2008). Ljekovite i aromatične biljke. Beograd i Novi Sad: Partenon Beograd i Srpska književna zadruga.

Kolak, I., Šatović, Z., Rukavina, H. i Rozić, I. (1997). Ljekovito bilje na hrvatskim prostorima. Sjemenarstvo, 14(5-6), 341-353.

Kolak, I., Šatović, Z., Rozić, I., Ivanković, M. (2002). Novi trendovi u proizvodnji ljekovitog i aromatičnog bilja. Sjemenarstvo, 19(3-4), 209-225.

Kolak, I., Šatović, Z., Carović, K. (2003). Ljekovito, aromatično i medonosno bilje-specijalni dio. Zagreb/Mostar. Skripta.

Komes, D., Bušić, A., Beľšcak-Cvitanović, A., Brnčić, M., Bosiljkov, T., Vojvodić, A. i Dujmić, F. (2017). Novel Approach to the Development of Functional Goat's Milk-Based Beverages Using Medicinal Plant Extracts in Combination with High Intensity Ultrasound Treatment. Food Technology and Biotechnology, 55(4), 484-495.

Koprivnjak, O. (2014). Kvaliteta, sigurnost i konzerviranje. Rijeka: Sveučilište u Rijeci, Medicinski fakultet.

Kremer, B. (2007). Ljekovito bilje. Zagreb: Begen d. o. o.

Matasović, D. (1997). Poznavanje prehrambene robe. Zagreb: Školska knjiga. 
B. Dorbić, Emilija Friganović, Marija Slipčević, Margarita Davitkovska, Zvezda Bogevska, Ana Vujošević / Senzorska procjena različitih oparaka od aromatičnog bilja / Glasilo Future (2019) 2(1-2) 44-58

Mitscher, L. A., Dolby, V. (1997). The green tea book: China's fountain of youth. New York: Avery Publishing Group.

Opletal, L., Volak, J. (2001). Bilje za zdravlje. Vaaždin: Stanek d. o. o.

Pahlov, M. (1989). Velika knjiga ljekovitog bilja. Ljubljana - Zagreb: Cankarjeva založba.

Paradžiković, N. (2014). Ljekovito i začinsko bilje (Nastavni materijal). Osijek: Sveučilište Josipa Jurja Strossmayera u Osijeku. Poljoprivredni fakultet u Osijeku.

Perl Pirički, A., Moslavac, T., Vugrinec, M. (2010). Prihvatljivost čaja od peršina kod adolescenata. Glasnik Zaštite Bilja, 33(1), 46-53.

Reto, M., Figueira, M. E., Filipe, H. M., Almeida, C. M. M. (2007). Chemical composition of green tea (Camellia sinensis) infusions commercialized in Portugal. Plant Food Hum. Nutr., 62(4), 139-144.

Slipčević, M. (2018). Senzorska procjena različitih oparaka od aromatičnog bilja. Završni rad. Veleučilište "Marko Marulić" u Kninu.

Šilješ, I., Grgesina, I., Grozdanić, Đ. (1992). Poznavanje, uzgoj i prerada ljekovitog bilja. Zagreb: Školska knjiga Zagreb.

Tadejevič, V., Jakovlić, V. (1976). Poznavanje robe s osnovama tehnologije i nauke o ishrani. Zagreb: Školska knjiga Zagreb.

Tucakov, J. (1978). Liječenje čajevima ljekovitog bilja. Zagreb: August Cesarec Zagreb.

Vahčić, N. (2013). Senzorske analize hrane, interna skripta za kolegij Senzorske analize hrane. Zagreb: Prehrambeno-biotehnološki fakultet Sveučilišta u Zagrebu.

Vickers, Z., Holton, E. (1998.): A comparison of taste test ratings, repeated consumption, and postconsumption ratings of differents trengths of iced tea. J. Sensory Stud., 13(2), 199-212.

Willfort, R. (2002). Ljekovito bilje i njegova upotreba. Zagreb: Erudit.

Zovkić, I. (1999). Naše ljekovito bilje i fitoterapija. Osijek: Gradska tiskara.

Primljeno: 06. lipnja 2019. godine

Prihvaćeno: 30 . lipnja 2019. godine
Received: Jun 06, 2019

Accepted: Jun 30, 2019 